\title{
ANCAMAN HOAX TERHADAP MEDIA MASSA
}

\section{Al Mutia Gandhi}

Institus Agama Islam Negeri Langsa

Dosen Fakultas Ushuluddin Adab dan Dakwah

Institut Agama Islam Negeri Langsa

Email : Almutia.gandhi@gmail.com

\begin{abstract}
Abstrak
Kemajuan teknologi dan informasi dewasa ini turut memberikan berbagai dampak positif dan negatif terhadap penyampaian sebuah pesan melalui media. Dimana pesan atau informasi yang ingin disampaikan melalui media sangat cepat untuk di ketahui khalayak. Terlebih pada media massa, informasi tersebut menyebar diberbagai media massa seperti facebook, instagram, twitter, whatsapp, berita online tanpa proses filterisasi sebuah pesan. Padahal kebenaran dari sebuah pesan akan mempengaruhi fikiran, emosi dan kepercayaan seseorang atau sekelompok orang dalam bertindak. Apabila pesan atau informasi tersebut berisi nilai kebohongan (Hoax) maka akan mempengaruhi kredibilitas sebuah media sebagai alat untuk menyampaikan sebuah pesan atau informasi. Sehingga media yang dalam hal ini bertindak sebagai perantara akan terancam reputasinya dan kepercayaan dari komunikan atau publik sebagai sebuah alat.
\end{abstract}

Kata Kunci : Ancaman, Hoax, Media Massa

\section{A. Pendahuluan}

Penggunaan media pada saat ini sangat berkembang pesat, terlebih lagi media massa. Media massa acap kali dijadikan sebagai wadah bagi setiap perkembangan informasi baik perseorangan maupun khalayak ramai. Pengguna media massa pun menggunakan informasi yang didapat sebagai acuan dalam bertindak baik secara pasif maupun aktif, tanpa melihat atau menyelidiki terlebih dahulu kebenaran dari suatu informasi. Pengguna media bagai mendewakan setiap informasi yang disampaikan adalah sebuah kebenaran yang tidak perlu di klarifikasi terlebih dahulu. Namun ketika pada saat nya kebenaran itu diketahui, maka pengguna akan menyalahkan media sebagai alat dari sebuah informasi tersebut. Hal ini lah 
yang akhirnya membuat citra buruk bagi sebuah media. Sehingga informasi yang disampaikan melalaui media kedepannya membuat pengguna nya menjadi ragu akan kebenaran sebuah fakta informasi.

Pada hakikatnya Media massa adalah salah satu sarana untuk memenuhi kebutuhan manusia akan informasi maupun hiburan. Media massa merupakan hasil produk teknologi modern sebagai saluran dalam komunikasi massa. Saluran yang disebut media massa tersebut diperlukan dalam berlangsungnya komunikasi massa.

Menurut (Cangara, 2006 : 36)Media massa adalah alat yang digunakan dalam penyampaian pesan-pesan dari sumber kepada khalayak (menerima) dengan menggunakan alat-alat komunikasi mekanis seperti surat kabar, film, radio, TV.

Sedangkan menurut (Rakhmat, 2004 : 17) Media massa adalah faktor lingkungan yang mengubah perilaku khalayak melalui proses pelaziman klasik, pelaziman operan atau proses imitasi (belajar sosial). Dua fungsi dari media massa adalah media massa memenuhi kebutuhan akan fantasi dan informasi.

Terdapat satu perkembangan media massa dewasa ini, yaitu ditemukannya internet. Kini masyarakat telah didominasi oleh media massa. Media massa begitu memenuhi keseharian hidup masyarakat yang tanpa disadari kehadiran dan juga pengaruhnya. Media massa memberi informasi, menghibur, menyenangkan, bahkan kadang mengganggu khalayak. Media mampu menggerakkan emosi atau mempengaruhi perasaan, menantang, dan mendefinisikan masyarakat serta membentuk realitas khalayak.Shirley Biagi ( Biagi, 2010:10) menyebutkan tiga konsep penting tentang media massa yaitu:

1. Media massa adalah suatu bentuk usaha yang berpusat pada keuntungan.

2. Perkembangan dan perubahan dalam pengiriman dan pengonsumsian media massa, dipengaruhi oleh perkembangan teknologi.

3. Media massa senantiasa mencerminkan sekaligus mempengaruhi kehidupan masyarakat, dunia politik, dan budaya.

Dari seluruh penjelasan di atas, dapat disimpullkan bahwa media massa merupakan saluran komunikasi massa guna menyampaikan informasi atau pesan kepada khalayak banyak secara luas. Media massa mempengaruhi hampir seluruh aspek kehidupan masyarakat, sosial, budaya, ekonomi, politik, dan sebagainya. Media massa mengumpulkan sejumlah uang untuk menyediakan informasi dan hiburan. Media massa juga merupakan bisnis yang pada keuntungan. Menurut sejarahnya, buku adalah media massa pertama, sedangkan internet adalah media massa terbaru. 
Permasalahan baru yang muncul pada saat ini bukan pada esensi dasar media massa sebagai perantara dari sebuah informasi dan hiburan, namun terletak pada penggunanya yang memanfaat kan media massa itu sebagai alat untuk menginformasikan segala bentuk hoax. Media acapkali menjadi tumbal dari segala macam bentuk hoax yang sengaja dibuat oleh sebahagian orang, dan malangnya hoax tersebut pun dipercayai oleh sebahagian orang sebagai sebuah kebenaran.

Media massa yang dalam hal ini banyak menggunakan jaringan internet sebagai induknya, hanya memerankan tugasnya sebagai media yang cukup cepat dalam menyebarkan sebuah informasi. Media massa tidak mempunyai tugas untuk memfilter informasi yang bertebaran, namun ketika sebuah fakta terungkap media massa seolah menjadi kambing hitam dari kesalahan pengguna dan penikmatnya.

\section{B. Dinamika Media Massa}

Perkembangan media massa dari tahun ke tahun mengalami perubahan yang sangat signifikan, hal ini dimulai sejak memasuki era reformasi. Pada massa ini media massa bagai baru terbebas dari mati surinya, dimana pada era orde baru media masa cukup dikekang eksistensinya.Melalui Permenpen yang baru pada tahun 1998 tentang SIUUP yang bias didapatkan dengan lebih mudah membuka jalan kepada pengusaha media untuk dapat berkembang. Pada tahun-tahun selanjutnya untuk merespon keinginan masyarakat, pengusaha dan pemerhati media penyiaran, DPR menyampaikan surat resmi yang ditandatangani oleh 26 anggota DPR mengenai usul inisiatif RUU tentang penyiaran, hingga pada tahun 2002 RUU Penyiaran pun di sahkan ( Hari, 2007 : 39).

Kebebasan media di era saat ini baik dengan telah disahkan RUU dan jaminan terhadap pers tidak semata - mata membebaskan media dalam berbagai persoalan. Kebebasan media menemukan persoalan baru yakni adanya pengguna media yang dirasa "kebablasan" dalam bertindak. Sehingga media massa dinilai "terlalu banyak bicara" dengan membesarbesarkan masalah dan mengeksploitasi konflik-konflik tertentu yang terjadi di masyarakat, sehingga tak jarang menimbulkan konflik baru, khususnya dibidang penyiaran ranah publik domain yang menjadi hak asasi masyarakat umum seperti di eksploitasi kekpentingan kekuasaan pemilik media. Pemilik dan dengan mudahnya menggunakan frekuensi vital milik masyarakat untuk kepnetingan politik maupun pribadinya. Adanya komodifikasi segala aspek oleh media menjadi penyakit pembodohan bagi masyarkat yang seharusnya memilki hat atas 
isi media massa yang menedukasi secara pintar dan menghibur secara nyata ( Masduki , 2007 :64).

Hal inilah yang dianggap sebagai cikal bakal hadirnya hoax pada media massa. Didasari adanya sebuah kepentingan tersembunyi dari sebahagian pihak yang memnfaatkan media massa tersebut. Diawali dengan melebihkan - lebih kan informasi dari sebuah fakta kemudian memangkas informasi penting yang harus disampaikan hingga menghadirkan sebuah kebohongan dalam informasi. Semua dilakukan semata- mata karena adanya kepentingan baik secara individu maupun kelompok tertentu.

Ketua Dewan Pers, Yosep Adi Prasetyo pada seiaran persnya mengatakan bahwa jumlah media massa di Indonesia merupakan yang terbanyak di dunia, jumlahnya saat ini mencapai 47.000 terdiri dari media cetak, radio, televisi dan berbasis daring. Dari jumlah media itu, menurutnya masih banyak yang asal- asalan saja, tidak memenuhi syarat sebagai sebuah media tetapi tetap bias eksis. Selain itu wartwan juga tidak semua memilki kompetensi dasar karena tidak memilki pengetahuan jurnalistik, tidak pula pernah mengikuti pelatihan jurnalistik. Ia merinci hingga saat ini baru terdaftar sekitar 14 ribu orang wartawan yang memilki kompetensi. Ia juga menghimbau kebebasan pers saat ini jangan dijadikan kesempatan untuk membuat berita bohong atau hoax, tapi meningkatkan kemampuan wartawan dan verifikasi media massa ( Wordpress.com, 2013 ).

Media sosial tidak hanya berfungsi sebagai media komunikasi saja tetapi tidak lepas dari dunia pergaulan sosial, dunia bisnis, dan pendidikan. Oleh karena itu media sangat memilki dampak bagi penggunanya baik positif maupun negatif. Dampak positif dengan adanya media sosial, yaitu :

a. Sumber informasi lebih mudah dan cepat didapatkan serta lebih transparan. Informasi yang ditemukan di media massa sangat beragam, mulai dari bahan pekerjaan, pendidikan, masakan, dll.

b. Media komunikasi memiliki jangkauan yang luas, kemudahan bagi pengguna dan biaya yang relative murah, Seperti penggunaan whatsapp yang selain untuk mengirimkan pesan bisa juga untuk melakukan panggilan video dengan biaya yang sangat minim.

c. Memperluas pergaulan, baik untuk terhubung dengan teman lama atau untuk menambah teman yang baru.

d. Bertukar informasi ataupun data seperti foto / video dengan mudah dan cepat

e. Ajang promosi dengan jangkauan yang lebih luas, mudah, murah namun fokus.

f. Untuk menikmati berbagai macam jenis hiburan 
g. Membangun opini atau mengemukakan pendapat secara luas. Suatu opini yang dibagikan lewat media social dapat menjadi viral dan menjangkau lintas Negara bahkan seluruh dunia.

h. Mempelajari sesuatu, seperti melihat tutorial pembuatan kue, baju, dll

Selain dampak positif, adapula dampak negative dari media massa, yaitu :

a. Terjadinya kesenjangan informasi, antara pengguna media massa dengan pihak yang tidak mendapatkan akses kepada media massa tersbut

b. Kecanduan terhadap media massa, ini terjadi apabila pengguna tidak dapat mengatur waktu dengan baik

c. Berkurang nya intensitas berkomunkasi secara langsung dengan sesama masyarakat

d. Menimbulkan kecemburuan sosial terhadap beberapa informasi pribadi di media massa

e. Memudahkan seseorang untuk memanipulasi identitas pribadinya

f. Pencurian indentitas pihak lain

g. Menciptakan isi berita yang bermuatan hoax

h. Mempermudah dalam penyebaran virus pada aplikasi computer ( Satrio, 2012:12)

Bebas berbagi dan menuliskan status di sosial media bukan berarti tidak ada batasan dan etika. Walau dari Facebook ataupun Twitter sendiri tidak mencantumkan (ataupun bila dicantumkan mungkin kita terlalu malas untuk membacanya), tetap saja ada etika yang tidak tetulis yang sewajarnya kita jalani dalam bersosial media. Etika ini bertujuan agar kita sebagai pengguna sosial media tidak terkena imbas buruk seperti kejahatan, penipuan dan lain sebagainya.

Etika dalam penulisan, etika dalam berbahasa dan berbicara di media sosial harus diperhatikan, salah-salah memposting sesuatu bisa berujung penjara atau tuntutan, intinya sebelum melakukan sesuatu dalam akun jejaring sosial, hendaknya di perhatikan 3 pola seperti Think before typing, Think before talking and Think before Posting ( Berikut beberapa etika dalam media massa :

1. Membatasi publikasi informasi mengenai kehidupan pribadi terutama yang sangat pribadi dan sensitive

Walau di Facebook dikolom update status bertuliskan “what's on your mind” bukan berarti kita bebas mengungkapkan segala yang kita rasakan di sosial media. Ada beberapa hal sensitif dan privasi yang seharusnya tidak perlu diketahui oleh semua orang. Semisal masalah keuangan, bertengkar dengan seseorang, pandangan kita terhadap seseorang dan lain 
sebagainya. Alangkah tidak bijaksananya bila semua orang tahu akan permasalahan dan problematika yang sedang kita hadapi. Baiknya simpan segala hal sensitif untuk diri sendiri dan tidak perlu semua teman di sosial media mengetahuinya.

2. Hati-hati bila check in place and mengupdate sedang dimana kita berada

Aplikasi untuk check in place seperti Foursquare memang banyak digunakan dan kemudian di share di sosial media. Pemilik akun sosial media suka check in place untuk memberitahu keberadaannya dan sedang melakukan apa. Tanpa disadari, check in place bisa mengundang orang yang berniat jahat kepada kita. Karena orang yang berniat jahat mengetahui dimana kita berada dan dengan siapa kita berada. Pergunakan media check in place dengan bijak

3. Tidak mengucapkan, mengetikkan, dan membagi konten yang memiliki unsur SARA dan Pornografi

Hindari berbicara ataupun menuliskan kalimat bercandaan yang memiliki unsur SARA ( Suku, Agama dan Ras) serta pornografi. Karena selain bisa menyinggung pihak lain juga bisa menimbulkan salah persepsi dan membawa dampak yang buruk. Tidak semua pengguna sosial media mengerti akan konsep ini, karena itu mulailah dari diri kita untuk tidak berbicara dan membagi konten yang mengandung unsur diatas.

4. Menghindarkan diri untuk mengupdate status yang berhubungan dengan privasi seperti dirumah sendiri atau mengambil uang di Bank

Update seperti ini bisa membahayakan diri sendiri. Bila ada orang berniat jahat, dia bisa mendatangi rumah kita ataupun mendatangi tempat kita berada.

5. Bersikap bijaksana dalam mencantumkan Personal Information

Personal information yang dimaksudkan adalah biodata yang ditampilkan di akun sosial media kita seperti alamat rumah, nomor telepon, tempat bersekolah, alamat email. Bila memang tidak penting, lebih baik tidak usah dicantumkan karena bisa dimanfaatkan oleh orang yang tidak bertanggungjawab. Semisal mengirim email atau sms penipuan dan lain sebagainya. Bila memang berniat mencantumkan, berhati-hatilah bila ada nomor telepon asing atau email dari pengirim yang tidak diketahui kita terima. 


\section{Menggunakan username dan foto profil asli}

Menurut pendapat beberapa orang, karakteristik dan sifat seseorang dapat dilihat dari penggunaan username. Selain itu penggunaan username dan foto profil asli penting digunakan pada suatu instansi maupun perusahaan.

\section{Menghindari penggunaan capslock}

Penggunaan capslock atau huruf kapital untuk mengetik semua huruf sangat tidak nyaman dibaca dan menyimbolkan bahwa kita sedang marah. Capslock dalam komunikasi tertulis sama dengan membentak atau berteriak

\section{Sejarah Hoax}

Hoax merupakan istilah yang cukup familiar sekarang ini terutama di kalangan pengguna media. Hoax merujuk kepada setiap informasi yang diragukan kebenarannya. Dalam cambridge dictionary, kata hoax sendiri berarti tipuan atau lelucon. Kegiatan menipu, trik penipuan, rencana penipuan disebut dengan hoax. Kemudian, situs hoaxes.org dalam konteks budaya mengarahkan pengertian hoax sebagai aktivitas menipu: Ketika koran sengaja mencetak cerita palsu, facebook sebagai sarana penyebaran berita palsu kita menyebutnya hoax. Kita juga menggambarkannya sebagai aksi publisitas yang menyesatkan, ancaman bom palsu, penipuan ilmiah, penipuan bisnis, dan klaim politik palsu sebagai hoax.

Istilah Hoax atau berita bohong ini sebenarnya sudah ada sejak ratusan tahun lalu. Istilah Hoax diperkirakan pertama kali muncul sekitar tahun 1808, dan merupakan istilah dalam bahasa inggris. hal ini tertulis dalam buku yang berjudul Sins Against Science karya Linda Walsh. Kata Hoax juga diyakini berasal dari kata-kata mantra para penyihir pada jaman dulu, yaitu "Hocus Pocus" yang berasal dari bahasa latin, yakni "Hoc est corpus", yang digunakan para penyihir untuk memperdaya orang lain dengan kata-kata mereka yang ternyata bohong. Penjelasan mengenai Hoax yang berarti suatu penipuan, juga dapat ditemukan dalam sebuah buku tahun 1965, yang berjudul Candle in the dark karya Thomas ady. Penggunaan kata Hoax mulai populer, sekitar tahun 2006. Yang didapat dari sebuah film berjudul Hoax, yang dibintangi oleh Richard Gere dan disutradarai oleh Lasse Halstorm.

Film Hoax ini sebenarnya diambil dari sebuah Novel hasil karya Clifford Irving yang juga berjudul Hoax, namun karena isi dari Film Hoax tersebut banyak melenceng dari Novel karyanya, Clifford Irving akhirnya mengundurkan diri dari pembuatan film Hoax tersebut. Sejak saat itu, Film Hoax ini dikenal sebagai suatu Film yang banyak berisikan tentang kebohongan-kebohongan, dan banyak orang yang menggunakan istilah Hoax untuk 
menggambarkan suatu berita bohong.

Berita Hoax yang awalnya digunakan sebagian orang untuk sekedar lelucon, kini menjadi semakin meresahkan. Berbagai pemberitaan bohong atau berita Hoax menyebar luas, dan kini menyebabkan berbagai hal negatif dan mulai meresahkan banyak kalangan. Oleh karena itu, diharapkan agar kita tidak dengan mudah menerima segala pemberitaan, apalagi suatu berita yang berisi tentang hal yang kurang masuk akal dan tidak jelas sumber beritanya. Perlu kita ingat, bahwa suatu berita Hoax, dapat tersebar dengan luas hanya dalam waktu yang singkat karena kebanyakan dari kita justru ikut menyebarluaskan berita tersebut. Tak jarang juga beberapa berita Hoax tersebut berisikan suatu ancaman atau ultimatum jika seseorang yang telah mengetahui berita tersebut akan mendapatkan kerugian atau musibah jika tidak turut menyebarkannya kepada orang lain.( Novita, $2016: 27$ )

Menurut pandangan psikologis, ada dua faktor yang dapat menyebabkan seseorang cenderung mudah percaya pada hoax. Orang lebih cenderung percaya hoax jika informasinya sesuai dengan opini atau sikap yang dimiliki (Respati, 2017 : 19). Contohnya jika seseorang penganut paham bumi datar memperoleh artikel yang membahas tentang berbagai teori konspirasi mengenai foto satelit maka secara naluri orang tersebut akan mudah percaya karena mendukung teori bumi datar yang diyakininya. Secara alami perasaan positif akan timbul dalam diri seseorang jika opini atau keyakinannya mendapat afirmasi sehingga cenderung tidak akan mempedulikan apakah informasi yang diterimanya benar dan bahkan mudah saja bagi mereka untuk menyebarkan kembali informasi tersebut. Hal ini dapat diperparah jika si penyebar hoax memiliki pengetahuan yang kurang dalam memanfaatkan internet guna mencari informasi lebih dalam atau sekadar untuk cek dan ricek fakta.

Terdapat empat mode dalam kegiatan penemuan informasi melalui internet, diantaranya adalah:

\section{a. Undirected viewing}

Pada undirected viewing, seseorang mencari informasi tanpa tahu informasi tertentu dalam pikirannya. Tujuan keseluruhan adalah untuk mencari informasi secara luas dan sebanyak mungkin dari beragam sumber informasi yang digunakan, dan informasi yang didapatkan kemudian disaring sesuai dengan keinginannya.

b. Conditioned viewing

Pada conditioned viewing, seseorang sudah mengetahui akan apa yang dicari, sudah mengetahui topik informasi yang jelas, Pencarian informasinya sudah mulai terarah. 


\section{c. Informal search}

Mode informal search, seseorang telah mempunyai pengetahuan tentang topik yang akan dicari. Sehingga pencarian informasi melalui internet hanya untuk menambah pengetahuan dan pemahaman tentang topik tersebut. Dalam tipe ini pencari informasi sudah mengetahui batasan-batasan sejauh mana seseorang tersebut akan melakukan penelusuran. Namun dalam penelusuran ini, seseorang membatasi pada usaha dan waktu yang ia gunakan karena pada dasarnya, penelusuran yang dilakukan hanya bertujuan untuk menentukan adanya tindakan atau respon terhadap kebutuhannya.

d. Formal search

Pada formal search, seseorang mempersiapkan waktu dan usaha untuk menelusur informasi atau topik tertentu secara khusus sesuai dengan kebutuhannya. Penelusuran ini bersifat formal karena dilakukan dengan menggunakan metodemetode tertentu. Tujuan penelusuran adalah untuk memperoleh informasi secara detail guna memperoleh solusi atau keputusan dari sebuah permasalahan yang dihadapi ( Turnbull, 1999 : 37).

Perilaku penyebaran hoax melalui internet sangat dipengaruhi oleh pembuat berita baik itu individu maupun berkelompok, dari yang berpendidikan rendah sampai yang tinggi, dan terstruktur rapi. ( Wopereis, $2000: 28$ ) menunjukkan bahwa terdapat perbedaan antara seseorang yang memiliki keahlian khusus dalam menggunakan search engine dengan orang yang masih baru atau awam dalam menggunakan search engine. Mereka dibedakan oleh pengalaman yang dimiliki. Individu yang memiliki pengalaman lebih banyak dalam memanfaatkan search engine, akan cenderung lebih sistematis dalam melakukan penelusuran dibandingkan dengan yang masih minim pengalaman (novice).

Berita hoax semakin sulit dibendung walaupun sampai dengan 2016 pemerintah telah memblokir 700 ribu situs, namun setiap harinya pula berita hoax terus bermunculan. Pada Januari 2017 pemerintah melakukan pemblokiran terhadap 11 situs yang mengandung konten negatif, namun kasus pemblokiran tersebut tidak sampai menyentuh meja hijau. Beberapa kasus di indonesia terkait berita hoax telah memakan korban, salah satunya berita hoax akan penculikan anak yang telah tersebar di beberapa media sosial dan menyebabkan orang semakin waspada terhadap orang asing. 


\section{Filterisasi Pesan Menghindari Hoax}

Ancaman berita hoax merupakan hal yang tidak bias dihindari sekarang ini Media sosial merupakan wadah yang sangat rentan dan sering digunakan sebagai tempat untuk menyebarkan berita hoax. Banyaknya pengguna aktif bahkan dapat dikatakan sebagai penggila media sosial di Indonesia ini sangat memudahkan pihak penyebar hoax dalam menjalankan aksinya. Dari hasil survey tentang wabah hoax nasional yang dilakukan oleh Mastel (2017) bahwa channel atau saluran penyebaran berita atau informasi yang berisi konten hoax tertinggi adalah dari media massa berupa facebook pada urutan tertinggi sebesar $92,40 \%$, aplikasi chatting $62,80 \%$, dan situs web34,90\%. Berdasarkan penelitian yang dilakukan Ruri Rosmalinda (2017) tentang "fenomena Penyesatan Berita Di Media Sosial” menyatakaSn bahwa pengaruh perkembangan teknologi bisa menjadi ancaman global termasuk terhadap Indonesia,khususnya terkait dengan penyebaran berita bohong (hoax).

Pihak-pihak penyebar hoax semakin dimudahkan karena kurangnya penyaringan berita di media sosial sehingga berita apa pun yang di-posting oleh seseorang dapat dengan mudahnya tersebar. Hadirnya media sosial banyak memberikan dampak positif tetapi tidak sedikit pula dampak negatifnya. Di Indonesia sendiri, kehadiran media sosial juga memberikan pengaruh terhadap perubahan politik, sosial, budaya dan ekonomi di Indonesia. Media sosial menggeser dan menembus batas dari pola relasi interaksi hirarkis menjadi egaliter, baik di ruang politik maupun budaya. Seorang warga negara biasa secara langsung dapat mengkritik dan berkomunikasi dengan Presidennya cukup hanya dengan mengirim mention ke akun Presiden di Instagram. Informasi yang kurang bahkan tidak bermutu bertebaran secara masif tanpa verifikasi dan konfirmasi.

Hoax, fitnah, dan hujatan bersahut-sahutan nyaris tanpa henti. Berdasarkan informasi dari situs web Kementerian Komunikasi dan Informatika Republik Inonesia, sepanjang tahun 2016 Direktorat Reskrimsus Polda Metro Jaya telah berhasil memblokir 300 lebih akun media sosial dan media online yang menyebarkan informasi hoax, provokasi, hingga SARA dari 800 ribu situs di Indonesia yang terisndikasi sebagai penyebar berita palsu dan ujaran kebencian yang sedang diawasi pemerintah ( Rafi, $2017: 23$ ).

Oleh karena itu filterisasi sebuah informasi yang disampaikan melaui media massa sangat perlu dilakukan, mengingat banyaknya masalah bahkan tindakan kriminal yang dapat terjadi akibat berita hoax tersebut.

Beberapa cara filterisasi yang dapat dilakuan untuk menghindari berita hoax tersebut menurut Nukman Luthfi dengan meningkatkan literasi media dan literasi media massa. Senada dengan hal diatas Kristiono (Ketua Umum Mastel) menegaskan pentingnya literasi 
dalam membentuk pemahaman masyarakat ketika menerima hoax, bagaimana cara mereka menghadapi berita palsu yang diterima. Selanjutnya menurut Sekretaris Kabinet Pramono Anung hoax bisa ditanggulangi dengaan istilah "swasensor" Swasensor adalah bagian dari literasi media di mana pengguna media sosial alias netizen harus selektif memilah mana informasi yang bohong dan yang benar. Swasensor diharapkan menjadi salah satu solusi untuk menangkal fenomena berita bohong alias 'hoax' di media sosial. Ia mengatakan, netizen seharusnya memiliki filter untuk tidak langsung percaya terhadap informasi yang beredar di media sosial, a para produsen hoax menjadi bukti nyata tersingkirnya nurani dan akal sehat karena dikalahkan oleh motif menjadi kaya dengan cepat dan mudah meskipun harus menghalalkan segala cara. Disisi lain untuk memanggulangi fenomena hoax yang sedang terjadi pemerintah telah membentuk Badan Siber Nasional. Lembaga baru itu bertugas melacak sumber kabar hoax dan melindungi situs pemerintah dari serangan peretas. Badan Siber institusi negara dari serangan peretas, kata Jurubicara Presiden, Johan Budi, (dikutip dari tribunnews.com). Menteri Koordisnator bidang Keamanan dan Politik, Wiranto, mengatakan langkah itu diperlukan untuk memerangi banjirnya berita palsu di intenet yang ikut mengkampanyekan kebencian. Disamping itu Pemerintah juga sedang mengupayakan percepatan penangan hoax, diantaranya melalui penangan hoax dimedia social salah satunya facebook, hal ini diungkapkan Menteri Komunikasi dan Informatika Rudiantara, pada Selasa. Menurut Rudiantara bahwa perlu ada kerja sama yang lebih intens agar penanganannya hoaxs bisa lebih cepat. Selain menjalin kerja sama dengan Facebook, Kemenkominfo juga berkoordinasi dengan komunitas masyarakat dan lembaga keagamaan seperti Majelis Ulama Indonesia (MUI), Rudiantara berharap komunitas dan lembaga keagamaan bisa berperan mengedukasi masyarakat agar lebih cermat dalam memilah berita-berita yang beredar di media sosial. Pengguna internet bisa melaporkan hoax tersebut melalui sarana yang tersedia di masing-masing media. Untuk Facebook, gunakan fitur Report Status dan kategorikan informasi hoax sebagai hatespeech/harrasment/rude/threatening, atau kategori lain yang sesuai. Jika ada banyak aduan dari netizen, biasanya Facebook akan menghapus status tersebut. Untuk Google, bisa menggunakan fitur feedback untuk melaporkan situs dari hasil pencarian apabila mengandung informasi palsu. Twitter memiliki fitur Report Tweet untuk melaporkan twit yang negatif, demikian juga dengan Instagram. Pengguna internet dapat mengadukan konten negatif ke Kementerian Komunikasi dan Informatika dengan melayangkan e-mail ke alamat aduankonten@mail.kominfo.go.id. ( Roida : 2017 ) 


\section{E. Kesimpulan}

Peristiwa penyebaran berita hoax yang sedang marak terjadi di Indonesia menyebabkan keresahan di masyarakat. Hal ini dapat di sikapi oleh para pengguna media sosial agar menjadi netter yang cerdas dan lebih selektif serta berhati-hati akan segala berita atau pun informasi yang tersebar. Diharapkan pula untuk tidak langsung percaya dari berita atau informasi yang diterima. Masyaralkat harus bergerak aktif untuk mencari tahu darimana sumber berita tersebut dan menggali informasi lebih jauh dari berita atau informasi yang didapat. Jangan mudah terprovokasi dengan menyebarluaskan kembali berita atau informasi yang belum jelas benar atau tidaknya. Jadilah pengguna media massa serta masyarakat Indonesia yang cerdas. Pemerintah diharapkan lebih cepat lagi merespon hoax yang beredar dimasyarakat sehingga dapat meminimalisasi kegaduhan atau keresahan yang terjadi dimasyrakat dan Pemerintah harus lebih giat lagi mensosialisasikan UU ITE agar masyarakat lebih paham lagi cara menggunakan media sosial dan internet dengan cerdas dan bijaksana dan kiraya media sosail dan internet digunakan untuk kebaikan hidup dan membaikkan kehidupan. 


\section{DAFTAR PUSTAKA}

Arismunandar, Satrio, 2012, Peran Media Massa dalam Pembentukan Karakter Bangsa, TP

Biagi, Shirley. 2010. Media/Impact: An Introduction to Mass Media, 9th. Penerjemah Mochammad Irfan danWulung Wira M. 2010. Media/Impact: Pengantar Media Massa, Edisi 9. Jakarta: Salemba Humanika.

Cangara, Hafied.2004. Pengantar Ilmu Komunikasi. Jakarta : PT. Radja Grafindo Persada.

Choo, C. W., Detlor, B., \& Turnbull, D. (1999). Information Seeking on the Web-An Integrated Model of Browsing and Searching. ASIS Annual Meeting, 5(2), 1-15.

Clara Novita, Literasi Media Baru Dan Penyebaran Informasi Hoax studi Fenomenologi Pada Pengguna Whatsapp Dalam Penyebaran Informasi Hoax Periode Januari-maret 2015, (tesis Universitas Gadjah Mada, 2016).

Jalaluddin, Rakhmat, 2002. Metode Penelitian Komunikasi. Bandung : PT. Remaja Rosdakarya

Lazonder, A. W., Biemans, H. J. a, \& Wopereis, I. G. J. H. (2000). Differences between novice and experienced users in search information on the World Wide Web.

Masduki, 2007, Regulasi Penyiaran : dari Otorite ke Liberal, Yokyakarta : Lkis

Rafi, M., 2017, Jurnal : ANALISIS PENYEBARAN BERITA HOAX DI INDONESIA, Jurusan Ilmu Komunikasi, Fakultas Ilmu Komunikasi Universitas Gunadarma

Respati, S. (2017, January 23). Mengapa Banyak Orang Mudah Percaya Berita "Hoax"? Kompas.com. Retrieved from

Wiryawan, Hari, 2007, Dasar-dasar Hukum Media, Yogyakarta : Pustaka Pelajar

Pakpahan, Roida (2017) Analisis Fenomena Hoax Diberbagai Media Sosial Dan Cara Menanggulangi Hoax. Konferensi Nasional Ilmu Sosial \& Teknologi (KNiST). pp. 479 484.

https://mubarok01.wordpress.com/2013/05/29/mediamassasaatini 